\title{
Species differences in the physiological activity of dietary lignan (sesamin and episesamin) in affecting hepatic fatty acid metabolism
}

\author{
Masayo Kushiro*, Yoko Takahashi and Takashi Ide \\ Laboratory of Nutritional Biochemistry, National Food Research Institute, 2-1-12 Kannondai, Tsukuba 305-8642, \\ Japan
}

(Received 22 April 2003 - Revised 6 October 2003 - Accepted 7 November 2003)

\begin{abstract}
The effect of sesame (Sesamum orientale) lignan preparation containing equivalent amounts of sesamin and episesamin on hepatic fatty acid metabolism was compared in rats, mice and hamsters. Animals were fed on either a diet free of lignan or a diet containing $2 \mathrm{~g}$ lignan/ $\mathrm{kg}$ for $15 \mathrm{~d}$. The lignan preparation greatly increased hepatic activity and the mRNA levels of enzymes involved in fatty acid oxidation, while it strongly down-regulated those of enzymes involved in lipogenesis in rats. In contrast, lignan did not modify these variables in mice and hamsters. Changes observed, if any, were more attenuated in these mice and hamsters than in rats. Sesamin and episesamin concentrations in serum and liver of animals fed on lignan-containing diets were significantly greater $(P<0.05)$ in rats than in mice and hamsters. Moreover, sesamin:episesamin values in tissues were far from that expected from the value in the lignan preparation given to the animals and were dependent on the animal species. Liver microsomes from each animal species degraded sesamin and episesamin in the presence of NADPH. The combined value of sesamin and episesamin degradation rates was lower in rats than in mice and hamsters. In addition, there was considerable diversity in the specificity of the enzyme reaction toward sesamin and episesamin among animal species. The differences in the amounts of lignan remaining in the tissues may account for the species dependence of the physiological activity of sesame lignan in affecting hepatic fatty acid oxidation and synthesis.
\end{abstract}

Sesame lignan: Fatty acid metabolism: Animal species

Sesamin is one of the most abundant lignans in sesame (Sesamum orientale) seeds and oil; it is epimerized during acid-clay bleaching in the oil-refining process to form episesamin (Fukuda et al. 1986). Therefore, commercial sesamin preparation contains both sesamin and episesamin at about a 1:1 ratio. We previously demonstrated that the lignan preparation profoundly and dose-dependently increased the activity and gene expression of fatty acid oxidation enzymes in the rat liver, presumably through the activation of PPAR $\alpha$ (Ashakumary et al. 1999); it also lowered the activity and gene expression of hepatic lipogenic enzymes through the down-regulation of sterol regulatory element binding protein (SREBP)-1 (Ide et al. 2001). Compared with sesamin, episesamin is more potent in increasing the activity and gene expression of fatty acid oxidation enzymes, while these compounds are equally effective in decreasing the variables for hepatic lipogenesis in rats (Kushiro et al. 2002). It is apparent that the lignan preparation has a strong influence on lipid metabolism in rats; alterations in hepatic fatty acid metabolism could account for the serum lipid-lowering effect of lignan in rats. However, information on the physiological effect of the lignan preparation on lipid metabolism in animal species other than rats is rather scarce. Hirata et al. (1996) reported that dietary lignan lowered serum cholesterol concentrations in human subjects. However, it is still important to clarify the physiological activity of the lignan in species other than rats before it is used as a supplement in the human diet. We therefore compared the effect of a lignan preparation containing both sesamin and episesamin on hepatic fatty acid metabolism in mice, hamsters and rats.

\section{Materials and methods \\ Animals and diets}

Male ICR mice (5 weeks old) and male Sprague-Dawley rats (4 weeks old) were obtained from Charles River, Kanagawa, Japan, and male Golden Syrian hamsters (Mesocricetus auratus; 5 weeks old) were obtained from Nihon SLC, Hamamatsu, Japan. Animals were housed individually in a room with controlled temperature $\left(20-22^{\circ} \mathrm{C}\right)$, humidity $(55-65 \%)$ and lighting (lights on from 07.00 to 19.00 hours) and fed on a commercial non-purified diet (type NMF; Oriental Yeast Co., Tokyo, Japan). After $7 \mathrm{~d}$ of 
acclimation to the housing conditions, mice, hamsters and rats were each randomly divided into two groups (eight per group), and fed on either a purified diet containing $2 \mathrm{~g}$ lignan (sesamin-episesamin $(1: 1, \mathrm{w} / \mathrm{w})) / \mathrm{kg}$ or a control diet free of lignan for $15 \mathrm{~d}$. The body weights at the start of the experiment were 30.8 (SD 1.9), 95.5 (SD 14.5) and 146.0 (SD 7.0) $\mathrm{g}$ for mice, hamsters and rats respectively. The basal composition of the experimental diet was (g/ $\mathrm{kg}$ ): casein 200, maize starch 150 , palm oil 100, cellulose 20, mineral mixture (American Institute of Nutrition, 1977) 35, vitamin mixture (American Institute of Nutrition, 1977) 10 , DL-methionine 3 , choline bitartrate 2 , saccharose 480. The lignan preparation was added to the experimental diets instead of saccharose. The lignan preparation was a gift from Kadoya Sesame Mills Inc., Kagawa, Japan. We followed the guidelines of our institute in the care and use of laboratory animals.

\section{Assays of the activities of enzymes in hepatic fatty acid oxidation and synthesis}

At the end of the experiments, the animals were anaesthetized using diethyl ether and killed by bleeding from the inferior vena cava, after which the livers were quickly excised. The liver was homogenized with $0.25 \mathrm{M}$-saccharose containing $1 \mathrm{mM}-\mathrm{EDTA}$ and $3 \mathrm{~mm}$-Tris-HCl (pH 7.2). We used $10.0 \mathrm{ml}$ saccharose solution/g to homogenize the livers of mice and hamsters, and $7.5 \mathrm{ml} / \mathrm{g}$ for rats. The homogenates were centrifuged at $200000 \mathrm{~g}$ for $30 \mathrm{~min}$. The activities of enzymes involved in fatty acid synthesis were measured spectrophotometrically using the supernatant fraction of the liver homogenate (Kabir \& Ide, 1996). Our preliminary experiments in rats showed that lipogenic enzyme activity in total liver homogenate was quantitatively recovered in supernatant fraction centrifuged at $200000 \mathrm{~g}$. Quantitative recovery of sub-cellular organelles containing enzyme activity involved in fatty acid oxidation was difficult. A considerable proportion (up to $50 \%$ ) of the activity of fatty acid oxidation enzymes and glutamate dehydrogenase (a marker enzyme for mitochondria) in total homogenate was precipitated even at a lowspeed centrifugation $(1000 \mathrm{~g}$ for $10 \mathrm{~min})$, and the recovery of enzyme activity in the supernatant fraction differed depending on the respective enzymes and nutritional status (Ashakumary et al. 1999). Therefore, use of the sub-cellular fraction as an enzyme source makes quantitative estimation of the changes in hepatic fatty acid oxidation difficult. We therefore used total homogenate to measure the activities of fatty acid oxidation enzymes in the current study. Peroxisomal fatty acid oxidation rate was measured according to the method of Mannaerts et al. (1979). The assay mixture $(2.5 \mathrm{ml})$ contained $4 \mathrm{mM}-$ ATP, $\quad 0.5 \mathrm{~mm}-\mathrm{CoA}, \quad 2 \mathrm{~mm}-\mathrm{NAD}, 2 \mathrm{~mm}$-dithiothreitol, $2 \mathrm{~mm}-\mathrm{KCN}, \quad 0.2 \mathrm{~mm}-\left[1-{ }^{14} \mathrm{C}\right]$ palmitoyl-CoA $\quad(7.4 \mathrm{kBq} /$ $\mu \mathrm{mol}$ ) and $0.1 \mathrm{ml}$ total homogenate in modified KrebsHenseleit bicarbonate buffer ( $\mathrm{pH} \mathrm{7.4)}$ (Mannaerts et al. 1979). Assays carried out in the absence of total homogenate served as blanks. After $5 \mathrm{~min}$ of incubation at $37^{\circ} \mathrm{C}$ in Erlenmeyer flasks, the enzyme reaction was terminated by pouring the mixture into test-tubes containing $0.625 \mathrm{ml}$ perchloric acid $(300 \mathrm{ml} / \mathrm{l})$ and acid-soluble radioactivity was measured by liquid scintillation counting. The activities of other enzymes involved in the fatty acid oxidation pathway, including carnitine palmitoyltransferase, acyl-CoA oxidase, 3-hydroxyacyl-CoA dehydrogenase and 3-ketoacyl-CoA thiolase, were measured spectrophotometrically as detailed previously (Kabir \& Ide, 1996; Ashakumary et al. 1999). The enzymes were analysed using an enzyme preparation stored at $-30^{\circ} \mathrm{C}$ for up to $10 \mathrm{~d}$. There are two carnitine palmitoyltransferases in mitochondria, one located in the outer mitochondrial membrane (carnitine palmitoyltransferase I) and the other located in the inner mitochondrial membrane (carnitine palmitoyltransferase II). Freezing-thawing mitochondria inactivates carnitine palmitoyltransferase I, but not II (McGarry \& Brown, 1997); this indicates that the transferase activity measured spectrophotometrically in freeze-thawed whole homogenate in the current study probably represents the carnitine palmitoyltransferase II activity.

\section{RNA analysis}

Hepatic RNA was extracted and the mRNA levels of enzymes in fatty acid metabolism were analysed by slotblot and Northern-blot hybridization using specific rat cDNA probes as detailed elsewhere (Ashakumary et al. 1999). Values were corrected for those of a housekeeping gene (glyceraldehyde-3-phosphate dehydrogenase). As we confirmed the specificity of our cDNA probes by Northern-blot analysis, mRNA abundance was estimated using slot-blot hybridization.

\section{Analysis of NADPH-dependent degradation of sesamin and episesamin by liver microsomes}

Mice, hamsters and rats at 7 weeks of age, fed on a commercial diet, were used to prepare liver microsomes. The liver was homogenized in 3 vol. $0 \cdot 25 \mathrm{M}$-saccharose containing $1 \mathrm{~mm}-\mathrm{EDTA}$ and $3 \mathrm{~mm}-\mathrm{Tris}-\mathrm{HCl}(\mathrm{pH} \mathrm{7.2)}$. The liver homogenates were centrifuged at $9000 \mathrm{~g}$ for $10 \mathrm{~min}$; the supernatant fractions were recentrifuged at $200000 \mathrm{~g}$ for $30 \mathrm{~min}$ to obtain microsomes, which were then suspended in the same mixture to use as an enzyme source. Degradation of sesamin and episesamin by liver microsomes was analysed in the reaction mixture (final volume $1 \mathrm{ml}$ ) containing $0.1 \mathrm{M}$-potassium phosphate buffer $(\mathrm{pH}$ 7.4), $1 \mathrm{mm-EDTA,} \quad 0 \cdot 15 \mathrm{mg} / \mathrm{ml} \quad 3$-((3-cholamidopropyl) dimethylammonio)-1-propanesulfonate, $5 \mathrm{~mm}$-dithiothreitol, $2 \mathrm{~mm}-\mathrm{NADPH}, 5 \mu \mathrm{M}$ each of sesamin and episesamin, and microsomes (20-400 $\mu$ g protein). Sesamin and episesamin were added to the reaction mixture in acetone solution $(10 \mu \mathrm{l})$ containing both of these compounds at a concentration of $0.5 \mathrm{~mm}$ each. The composition of the reaction mixture was similar to that reported by Chiang (1991) for the analysis of cholesterol $7 \alpha$-hydroxylase activity in rat liver microsomes. The enzyme reaction was triggered by adding microsomes and incubated at $37^{\circ} \mathrm{C}$ with shaking (eighty oscillations per min). After 10-180 min incubation, the reaction was stopped by adding $20 \mathrm{ml}$ chloroformmethanol $(2: 1, \mathrm{v} / \mathrm{v})$. Sesamin and episesamin remaining in the lipid extract were analysed by reversed-phase HPLC using a Capcell Pak AG 120 A $\mathrm{C}_{18}$ column 
$(250 \times 4.6 \mathrm{~mm} ;$ Shiseido, Tokyo, Japan $)$ with a mobile phase of methanol-water $(7: 3, \mathrm{v} / \mathrm{v})$ at a flow rate of $1.0 \mathrm{ml} / \mathrm{min}$, monitoring with a fluorometer at excitation of $298 \mathrm{~nm}$ and emission of $325 \mathrm{~nm}$. Lignan degradation rates were calculated by subtracting the amounts of sesamin and episesamin remaining in the incubation mixture from those presented in the original mixture. Inclusion of NADPH in the reaction mixture was found to be obligatory to detect degradation of lignans, and no degradation occurred in the absence of this cofactor. Using 1, 2 and $5 \mathrm{mM}-\mathrm{NADPH}$ in the incubation mixture, the rate of degradation increased only slightly as the concentrations of NADPH increased. We therefore routinely employed $2 \mathrm{mM}-\mathrm{NADPH}$ to measure the enzyme reaction. Insolubility of sesamin and episesamin in the enzyme mixture made the kinetic analysis of enzyme reaction difficult. We added these lignans in a small volume of acetone to the incubation media. The amounts of sesamin and episesamin degraded by rat microsomes (100 $\mu$ g protein) during a $30 \mathrm{~min}$ incubation using $5.0 \mu \mathrm{M}$ substrate $(2.5 \mu \mathrm{M}$ each of sesamin and episesamin) were 0.653 and $0.422 \mathrm{nmol}$ for sesamin and episesamin (mean values of duplicate analyses) respectively. The values approximately doubled (1.490 and $0.935 \mathrm{nmol}$ respectively) using $10.0 \mu \mathrm{M}$ substrate $(5.0 \mu \mathrm{M}$ each of sesamin and episesamin). However, when using concentrations of lignan $>10.0 \mu \mathrm{M}$, the results obtained were very variable, and they sometimes became even lower than those obtained with 5.0 or $10.0 \mu \mathrm{M}$ substrate, presumably because of the precipitation of the lignan in the incubation mixture. Therefore, we routinely used $10.0 \mu \mathrm{M}$ concentrations of lignan substrate $(5.0 \mu \mathrm{M}$ each of sesamin and episesamin) to measure the lignan degradation rate, in spite of the fact that the concentration may not be high enough to obtain maximal enzyme activity. Solubilization of lignan substrate using Triton X-100 was unsuccessful. Triton X-100 at a final concentration of $1 \mathrm{~g} / \mathrm{l}$ incubation mixture totally inactivated the enzyme reaction.

\section{Analyses of serum lipids and insulin, and sesame lignan}

Serum triacylglycerol, cholesterol, phospholipid and NEFA concentrations were assayed using commercial enzyme kits (Wako Pure Chemical, Osaka, Japan). Serum insulin levels in rats and mice were analysed by a commercial ELISA kit (Morinaga, Kanagawa, Japan) using rat and mouse insulin as standards respectively. Serum and liver lipids were extracted and purified (Folch et al. 1957). Sesamin and episesamin contents in the liver- and serum-lipid extracts were analysed by HPLC.

\section{Statistical analyses}

StatView for Macintosh was used for statistical analysis (SAS Institute Inc., Cary, NC, USA). Data for the activities of hepatic enzymes of fatty acid oxidation and synthesis and serum lipid and insulin concentrations were analysed by two-way ANOVA to establish the effect of animal species and lignan or any interaction between these two factors. If there was a significant animal species $\times$ lignan interaction in the two-way ANOVA, all the significant differences of the mean values at $P<0.05$ were inspected by a Tukey-Kramer post hoc analysis. If two-way ANOVA detected any significant effect of animal species or lignan but no significant interaction between these factors, a Tukey-Kramer post hoc analysis was performed for the values segregated according to animal species or lignan to determine significant differences among the factor levels. Lignan-dependent alterations of the mRNA levels in each animal species were analysed by the Student's $t$ test. Other data for one-way classification were analysed by one-way ANOVA. This was followed by a Tukey-Kramer post hoc analysis to detect significant differences in the mean values at $P<0.05$.

\section{Results}

Activities of hepatic enzymes involved in fatty acid oxidation and synthesis

Dietary lignan did not affect food intake and growth of mice, hamsters and rats. Body weights at the time of killing were 38.0 (SD 3.0), 118.0 (SD 8.0) and 276.0 (SD 12.0) $\mathrm{g}$ for mice, hamsters and rats respectively.

Species-dependent differences in the physiological activity of dietary lignan in affecting the activities of various hepatic fatty acid oxidation enzymes were observed among mice, hamsters and rats; analysis by two-way ANOVA revealed that significant interactions between two factors, i.e. animal species and lignan, existed in all the variables analysed. Consistent with previous studies (Ashakumary et al. 1999; Ide et al. 2001; Kushiro et al. 2002), dietary lignan caused great increases in the activity of hepatic fatty acid oxidation enzymes in rats (Table 1). However, it was observed that dietary lignan was irrelevant in increasing the activity of hepatic fatty acid oxidation enzymes in mice and hamsters.

The effects of lignan on the activity of hepatic lipogenic enzymes were examined. Pyruvate kinase, an enzyme involved in the glycolytic pathway in the liver, is coordinately regulated with other enzymes involved in lipogenesis, and is considered to participate in the regulation of fatty acid synthesis (Inoue et al. 1986; Noguchi et al. 1992). Two-way ANOVA showed that there were significant $(P<0.05)$ animal species $\times$ lignan interactions for all the enzyme activities. We previously demonstrated that lignan decreased the activities of various lipogenic enzymes, including acetyl-CoA carboxylase, fatty acid synthase, ATP-citrate lyase, pyruvate kinase and glucose6-phosphate dehydrogenase in rat liver (Ashakumary et al. 1999; Ide et al. 2001; Kushiro et al. 2002). Consistent with this observation, lignan greatly decreased the hepatic activities of lipogenic enzymes in the rat in the current study. However, lignan did not affect the lipogenic enzyme activities in mice. Although lignan significantly decreased $(P<0.05)$ the activities of ATP-citrate lyase and pyruvate kinase in hamsters, the extent of these reductions was much less than those observed in rats. The activities of fatty acid synthase and glucose-6-phosphate dehydrogenase were indistinguishable between hamsters fed on the lignan-free and $2 \mathrm{~g}$ lignan $/ \mathrm{kg}$ diets. 
Table 1. Effect of lignan on the activities of enzymes ( $\mu \mathrm{mol} / \mathrm{min}$ per $\mathrm{g}$ liver) involved in hepatic fatty acid oxidation and synthesis in the mouse, hamster and rat $\dagger$ (Mean values and standard deviations for eight animals per group)

\begin{tabular}{|c|c|c|c|c|c|c|c|c|c|c|c|c|c|c|c|}
\hline \multirow[b]{3}{*}{ Enzyme activity } & \multicolumn{4}{|c|}{ Mouse } & \multicolumn{4}{|c|}{ Hamster } & \multicolumn{4}{|c|}{ Rat } & \multicolumn{3}{|c|}{$\begin{array}{c}\text { Statistical significance of } \\
\text { effect (two-way ANOVA): } \\
P \text { value }\end{array}$} \\
\hline & \multicolumn{2}{|c|}{ Lignan-free } & \multicolumn{2}{|c|}{ Lignan } & \multicolumn{2}{|c|}{ Lignan-free } & \multicolumn{2}{|c|}{ Lignan } & \multicolumn{2}{|c|}{ Lignan-free } & \multicolumn{2}{|c|}{ Lignan } & \multirow[b]{2}{*}{ Animal } & \multirow[b]{2}{*}{ Lignan } & \multirow{2}{*}{$\begin{array}{c}\text { Animal } \times \\
\text { Lignan }\end{array}$} \\
\hline & Mean & SD & Mean & SD & Mean & SD & Mean & SD & Mean & SD & Mean & SD & & & \\
\hline \multicolumn{16}{|c|}{ Fatty acid oxidation enzymes } \\
\hline $\begin{array}{l}\text { Carnitine } \\
\text { palmitoyltransferase }\end{array}$ & $0.977^{b}$ & 0.148 & $0.882^{d}$ & 0.160 & $0.783^{\mathrm{ab}}$ & 0.075 & $0.761^{d}$ & $0 \cdot 140$ & $0.571^{a}$ & $0 \cdot 100$ & $1 \cdot 250^{* e}$ & 0.230 & 0.007 & $<0.001$ & $<0.001$ \\
\hline $\begin{array}{l}\text { Peroxisomal fatty acid } \\
\text { oxidation }\end{array}$ & $0.980^{\mathrm{b}}$ & 0.190 & $1 \cdot 160^{\text {de }}$ & 0.450 & $1 \cdot 250^{\mathrm{b}}$ & 0.140 & $1.390^{\mathrm{e}}$ & 0.080 & $0.306^{\mathrm{a}}$ & 0.054 & $1.050^{* d}$ & $0 \cdot 110$ & $<0.001$ & $<0.001$ & $<0.001$ \\
\hline Acyl-CoA oxidase & $1 \cdot 17^{b}$ & 0.24 & $1.35^{\mathrm{e}}$ & 0.41 & $1.92^{\mathrm{C}}$ & 0.15 & $1.89^{f}$ & 0.12 & $0.22^{a}$ & 0.05 & $0.79^{* d}$ & 0.07 & $<0.001$ & $<0.001$ & 0.001 \\
\hline $\begin{array}{l}\text { 3-Hydroxyacyl-CoA } \\
\text { dehydrogenase }\end{array}$ & $80 \cdot 4$ & $9 \cdot 8$ & $68 \cdot 7^{d}$ & $12 \cdot 2$ & $110 \cdot 0$ & $19 \cdot 0$ & $128 \cdot 0^{\mathrm{e}}$ & $22 \cdot 0$ & $101 \cdot 0$ & $12 \cdot 0$ & $191 \cdot 0^{\star f}$ & $40 \cdot 0$ & $<0.001$ & $<0.001$ & $<0.001$ \\
\hline $\begin{array}{l}\text { 3-Ketoacyl-CoA } \\
\text { thiolase }\end{array}$ & $46 \cdot 1^{b}$ & $5 \cdot 7$ & $40 \cdot 3^{d}$ & $7 \cdot 2$ & $39 \cdot 4^{\mathrm{ab}}$ & $4 \cdot 4$ & $45 \cdot 0^{d}$ & $9 \cdot 8$ & $31 \cdot 7^{\mathrm{a}}$ & $8 \cdot 0$ & $57 \cdot 0^{\star e}$ & $7 \cdot 9$ & 0.716 & $<0.001$ & $<0.001$ \\
\hline \multicolumn{16}{|l|}{ Lipogenic enzymes } \\
\hline Fatty acid synthase & $1 \cdot 72^{\mathrm{a}}$ & 0.39 & $1.68^{\mathrm{d}}$ & 0.27 & $5 \cdot 36^{\mathrm{b}}$ & 0.27 & $4 \cdot 23^{\mathrm{e}}$ & 0.47 & $4 \cdot 64^{\mathrm{b}}$ & 1.72 & $1.98^{* d}$ & 0.55 & $<0.001$ & $<0.001$ & $<0.001$ \\
\hline ATP-citrate lyase & $3.59^{\mathrm{a}}$ & 1.04 & $2 \cdot 66$ & 0.66 & $6 \cdot 85^{\mathrm{b}}$ & 1.76 & $4 \cdot 66^{\star}$ & 0.76 & $8 \cdot 91^{\mathrm{b}}$ & $2 \cdot 29$ & $3.98^{\star}$ & 1.22 & $<0.001$ & $<0.001$ & 0.001 \\
\hline $\begin{array}{l}\text { Glucose-6-phosphate } \\
\text { dehydrogenase }\end{array}$ & $1.94^{\mathrm{a}}$ & $1 \cdot 12$ & $1 \cdot 22^{\mathrm{d}}$ & 0.47 & $0.61^{a}$ & $0 \cdot 10$ & $0.59^{d}$ & 0.09 & $14 \cdot 0^{\mathrm{b}}$ & $2 \cdot 7$ & $4 \cdot 81^{\star e}$ & 1.56 & $<0.001$ & $<0.001$ & $<0.001$ \\
\hline Pyruvate kinase & $30 \cdot 5^{\mathrm{a}}$ & $11 \cdot 0$ & $29.3^{\mathrm{e}}$ & $7 \cdot 6$ & $67 \cdot 9^{\mathrm{c}}$ & $5 \cdot 1$ & $58 \cdot 9^{\star f}$ & $6 \cdot 8$ & $44.7^{\mathrm{b}}$ & $7 \cdot 8$ & $16 \cdot 3^{\text {*d }}$ & 4.5 & $<0.001$ & $<0.001$ & $<0.001$ \\
\hline
\end{tabular}

a,b,c Mean values among groups of animals fed a lignan-free diet with unlike superscript letters were significantly different $(P<0.05)$

$\mathrm{d}, \mathrm{e}, \mathrm{f}$ Mean values among groups of animals fed a $2 \mathrm{~g}$ lignan $/ \mathrm{kg}$ diet with unlike superscript letters were significantly different $(\boldsymbol{P}<0.05)$.

* Mean values were significantly different from the corresponding group of animals fed a lignan-free diet: ${ }^{*} P<0.05$.

†For details of diets and procedures, see pp. 377-378. 
mRNA level in hepatic enzymes involved in fatty acid oxidation and synthesis

To confirm the results obtained with enzyme activity, we analysed the mRNA levels of various enzymes involved in hepatic fatty acid oxidation and synthesis in rats and mice, (slot-blot hybridization using specific cDNA probes of rat origin; Table 2). The results obtained using Northern-blot hybridization revealed that our rat cDNA probes successfully and specifically detected mRNA of various enzymes in both mice and rats (Fig. 1). However, our rat cDNA probes gave very weak signals for mRNA of various enzymes in hamsters and it was difficult to obtain reliable values. Therefore, the mRNA levels were analysed in mice and rats, but not in hamsters. The values were corrected for those of a housekeeping gene, glucose-6-phosphate dehydrogenase. It is considered that the intensity of signal obtained for a specific mRNA molecule using a rat cDNA probe may not be identical between mouse and rat, and thus it is difficult to compare the values observed in different animal species. Therefore, the mRNA levels of mice and rats fed on the lignan-containing diet were expressed as percentages, assigning the values in a group of respective animal species fed on a lignan-free diet to 100; statistical analyses of lignan-dependent alterations in the mRNA levels were evaluated using the Student's $t$ test.

Lignan increased the mRNA levels of various mitochondrial and peroxisomal fatty acid oxidation enzymes in rats. Dietary lignan slightly but significantly $(P<0.05)$ increased the mRNA level of peroxisomal 3-ketoacyl$\mathrm{CoA}$ thiolase in mice. However, no other significant lignan-dependent alterations in the mRNA levels of fatty acid oxidation enzymes were confirmed in this animal species.

Analysis of the mRNA levels of enzymes involved in fatty acid synthesis by slot-blot hybridization confirmed the results obtained on enzyme activity. Dietary lignan strongly reduced the mRNA levels of lipogenic enzymes in rats. However, lignan-dependent alteration in the levels of mRNA for all the lipogenic enzymes was not observed in mice.

\section{Serum lipid and insulin concentrations}

Among groups of animals fed on the experimental diets, two-way ANOVA showed that there was a significant animal species $\times$ lignan interaction for serum triacylglycerol $(P<0.005)$ and phospholipid $(P<0.025)$ concentrations (Table 3$)$; subsequent post hoc analysis revealed that lignan significantly decreased $(P<0.05)$ these variables in rats, but not in the other animal species. Twoway ANOVA did not detect a significant effect of lignan or a significant animal species $\times$ lignan interaction; dietary lignan, however, caused 16 and $26 \%$ decreases in the serum cholesterol and NEFA levels in rats respectively, but the values were approximately the same between the groups fed the lignan-free and lignan-containing diets in the other animal species. We also analysed serum insulin concentrations in rats and mice. Because of the large variation in the values, especially in mice, two-way ANOVA did not detect significant effects of animal species or lignan, or an animal species $\times$ lignan interaction for this variable. However, dietary lignan caused a decrease of $52 \%$ in the serum insulin concentration in rats, but did not affect the variable in mice.

\section{Sesamin and episesamin concentrations in the serum and liver}

We analysed the serum and hepatic concentrations of sesamin and episesamin in the animals fed on the diet containing $2 \mathrm{~g}$ lignan (sesamin-episesamin $(1: 1, \mathrm{w} / \mathrm{w})) / \mathrm{kg}$. In both the serum and liver, the sesamin and episesamin levels were much greater in rats than in mice and hamsters

Table 2. Effects of lignan on mRNA levels (\%) of enzymes involved in hepatic fatty acid oxidation and synthesis in the mouse and rat†

(Mean values and standard deviations for eight animals per group)

\begin{tabular}{|c|c|c|c|c|c|c|c|c|}
\hline \multirow[b]{3}{*}{ mRNA level } & \multicolumn{4}{|c|}{ Mouse } & \multicolumn{4}{|c|}{ Rat } \\
\hline & \multicolumn{2}{|c|}{ Lignan-free } & \multicolumn{2}{|c|}{ Lignan } & \multicolumn{2}{|c|}{ Lignan-free } & \multicolumn{2}{|c|}{ Lignan } \\
\hline & Mean & SD & Mean & SD & Mean & SD & Mean & SD \\
\hline \multicolumn{9}{|l|}{ Fatty acid oxidation enzymes } \\
\hline \multicolumn{9}{|l|}{ Mitochondrial enzymes } \\
\hline Carnitine palmitoyltransferase II & 100 & 14 & 108 & 16 & 100 & 12 & $170^{*}$ & 37 \\
\hline Trifunctional enzyme subunit $\alpha$ & 100 & 18 & 94 & 22 & 100 & 15 & $245^{\star}$ & 37 \\
\hline Trifunctional enzyme subject $\beta$ & 100 & 34 & 73 & 17 & 100 & 30 & $226^{*}$ & 50 \\
\hline Mitochondrial 3-ketoacyl-CoA thiolase & 100 & 17 & 92 & 8 & 100 & 25 & $242^{*}$ & 69 \\
\hline \multicolumn{9}{|l|}{ Peroxisomal enzymes } \\
\hline Acyl-CoA oxidase & 100 & 21 & 120 & 28 & 100 & 12 & $335^{\star}$ & 82 \\
\hline Peroxisomal bifunctional enzyme & 100 & 20 & 125 & 31 & 100 & 17 & $1026^{*}$ & 401 \\
\hline Peroxisomal 3-ketoacyl-CoA thiolase & 100 & 11 & $138^{*}$ & 19 & 100 & 18 & $499^{*}$ & 103 \\
\hline \multicolumn{9}{|l|}{ Lipogenic enzymes } \\
\hline Fatty acid synthase & 100 & 38 & 103 & 39 & 100 & 34 & $37^{*}$ & 13 \\
\hline ATP-citrate lyase & 100 & 12 & 108 & 22 & 100 & 24 & $55^{\star}$ & 13 \\
\hline L-Pyruvate kinase & 100 & 21 & 113 & 32 & 100 & 21 & $36^{*}$ & 7 \\
\hline
\end{tabular}

${ }^{*}$ Mean values were significantly different from those of the corresponding group of animals fed a lignan-free diet: ${ }^{*} P<0.05$.

†For details of diets and procedures, see pp. 377-378. 
Mouse

123456

A

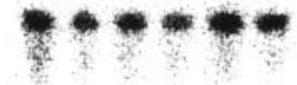

B

C 28 enses

D

$\mathbf{E}$

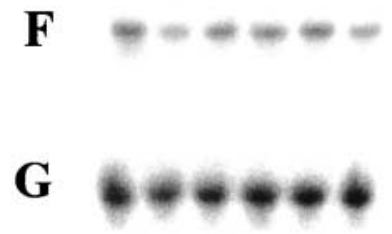

Rat
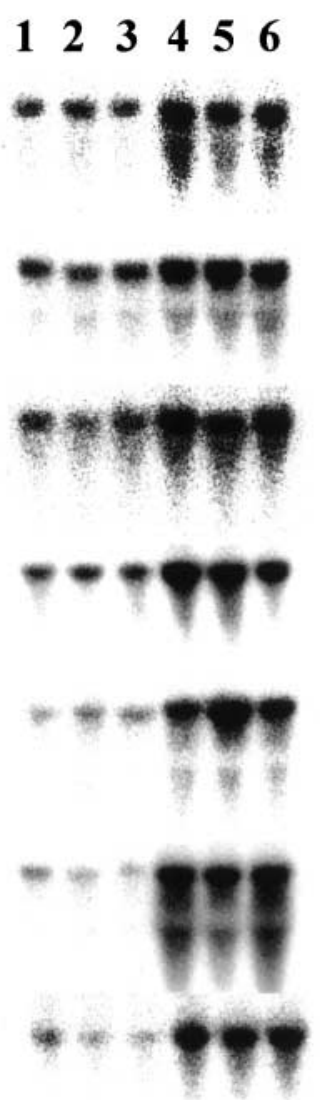

Mouse 123456

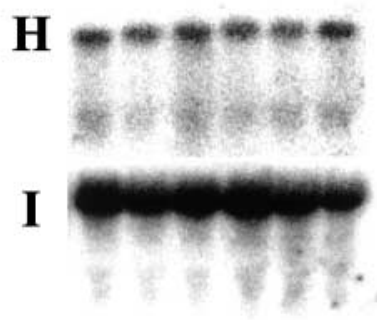

J

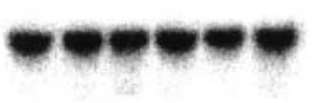

Rat

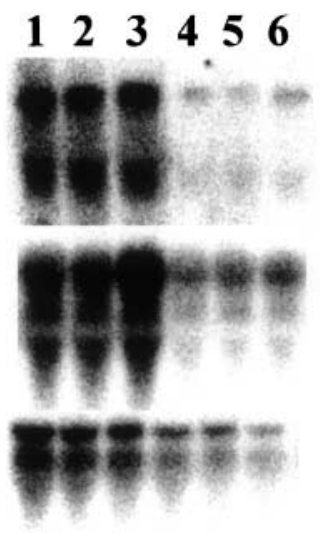

Fig. 1. Northern-blot analysis of mRNA of hepatic enzymes involved in fatty acid oxidation and synthesis in mice and rats. RNA samples $(30 \mu \mathrm{g})$ were denatured and subjected to electrophoresis on $11 \mathrm{~g}$ agarose/l gel containing $0.66 \mathrm{M}$-formaldehyde, then transferred to a nylon membrane and fixed with UV irradiation. RNA on nylon membranes was hybridized with radiolabelled cDNA probes specific for mRNA of carnitine palmitoyltransferase II. (A), mitochondrial trifunctional enzyme; (B), subunit $\alpha ;(C)$, subunit $\beta$; (D), mitochondrial 3-ketoacyl-CoA thiolase; $(E)$, acyl-CoA oxidase; $(F)$, peroxisomal bifunctional enzyme; $(G)$, peroxisomal 3-ketoacyl-CoA thiolase; $(H)$, fatty acid synthase; (I), ATPcitrate lyase; (J), L-pyruvate kinase. Lanes 1-3: RNA from animals fed a lignan-free diet; lanes 4-6: RNA from animals fed a $2 \mathrm{~g}$ lignan/kg diet. For details of diets and procedures, see pp. 377-378.

(Table 4). Despite the fact that the lignan preparation given to the experimental animals contained both sesamin and episesamin at a 1:1 ratio, relative abundances of these lignans in the serum and liver were differed considerably according to animal species. The concentration of episesamin was much greater than that of sesamin in both the serum and liver in rats (sesamin:episesamin values 0.26 and 0.41 for the serum and liver respectively). Although the concentrations of these compounds in the serum and liver were much lower in mice, sesamin was more predominant than episesamin in this animal species (sesamin: episesamin values 3.70 and 2.10 for the serum and liver respectively). In hamsters, the serum concentrations were comparable between sesamin and episesamin (value 1.20), while the liver contained twice as much episesamin as sesamin (sesamin:episesamin value 0.48).

\section{Degradation of sesamin and episesamin by liver microsomes}

We found that sesamin and episesamin were degraded by liver microsomes (Table 5). Preliminary experiments using $10-180 \mathrm{~min}$ incubation and $25-400 \mu \mathrm{g}$ microsomal protein from various animal species revealed that lignan degradation was linear with respect to incubation time and enzyme amount, up to $30 \mathrm{~min}$ and $100 \mu \mathrm{g}$ microsomal protein. Enzyme reactions using $100 \mu \mathrm{g}$ microsomal protein obtained from five animals from each animal species were carried out for 15 and $30 \mathrm{~min}$ and the data were statistically analysed. Total degradation rate combining the values for sesamin and episesamin was considerably lower in rats than in the other animal species. At $15 \mathrm{~min}$, the difference between the values for hamsters and rats was statistically significant $(P<0.05)$, and at $30 \mathrm{~min}$ the value became significantly lower $(P<0.05)$ in rats than in the other animal species. In the absence of NADPH, no significant degradation of these lignans during $30 \mathrm{~min}$ incubation was observed using microsomes from various animal species. Differences in the substrate specificity of the enzyme reaction among animal species were observed. The reaction rate was greater for episesamin than for sesamin in mice and vice versa in hamsters. Rat enzyme metabolizes sesamin at a rate slightly higher than that of episesamin. 
Table 4. Sesamin and episesamin concentrations in the serum $(\mu \mathrm{mol} / \mathrm{l})$ and liver $(\mathrm{nmol} / \mathrm{g})$ of the mouse, hamster and rat fed a lignan-containing diet ${ }^{\star}$

(Mean values and standard deviations for eight animals per group)

\begin{tabular}{|c|c|c|c|c|c|c|}
\hline & \multicolumn{2}{|c|}{ Mouse } & \multicolumn{2}{|c|}{ Hamster } & \multicolumn{2}{|c|}{ Rat } \\
\hline & Mean & SD & Mean & SD & Mean & SD \\
\hline \multicolumn{7}{|l|}{ Serum } \\
\hline Sesamin & $3.06^{a}$ & 1.34 & $2 \cdot 15^{\mathrm{a}}$ & 2.68 & $22 \cdot 10^{\mathrm{b}}$ & $10 \cdot 30$ \\
\hline Episesamin & $0.82^{a}$ & 0.5 & $1.84^{\mathrm{a}}$ & 1.99 & $86 \cdot 40^{\mathrm{b}}$ & 27.50 \\
\hline Total & $3.88^{a}$ & 1.73 & $3.99^{a}$ & 4.66 & $108.00^{\mathrm{b}}$ & 33.0 \\
\hline \multicolumn{7}{|l|}{ Liver } \\
\hline Sesamin & $1 \cdot 30^{a}$ & $1 \cdot 12$ & $0.28^{a}$ & 0.18 & $3 \cdot 31^{b}$ & 1.80 \\
\hline Episesamin & $0.61^{a}$ & 0.62 & $0.58^{\mathrm{a}}$ & 0.40 & $8 \cdot 1^{\mathrm{b}}$ & 3.14 \\
\hline Total & $1.91^{a}$ & 1.73 & $0.86^{\mathrm{a}}$ & 0.57 & $11.40^{\mathrm{b}}$ & 4.87 \\
\hline
\end{tabular}

${ }^{a, b}$ Mean values with unlike super script letters were significantly different $(P<0.05)$.

${ }^{*}$ For details of diets and procedures, see pp. 377-378.

\section{Discussion}

It has been reported that the lignan preparation containing both sesamin and episesamin has various physiological effects, including antioxidant (Yamashita et al. 2000) and anti-carcinogen (Hirose et al. 1992) activities, lowering of blood pressure (Matsumura et al. 1998), modulation of immune function ( $\mathrm{Gu}$ et al. 1995; Nonaka et al. 1997; $\mathrm{Gu}$ et al. 1998) and lowering of serum lipids (Hirose et al. 1991; Ashakumary et al. 1999) in experimental animals. However, most studies have been carried out using rats as an experimental animal, and there have only been a few studies (Akimoto et al. 1993; Ogawa et al. 1994; Chavali et al. 1997) on other animal species.

We previously demonstrated that lignan (sesamin- episesamin $(1: 1, w / w))$ increased hepatic fatty acid oxidation, while it down-regulated lipogenesis and thus accompanied lowering of serum lipid levels in rats (Ashakumary et al. 1999). However, the physiological activity of the lignan preparation in affecting hepatic fatty acid oxidation and synthesis remained to be studied in other animal species. In the present study, we compared the physiological activities of lignan in mice, hamsters and rats. Consistent with previous studies, dietary lignan strongly increased the activity and gene expression of hepatic fatty acid oxidation enzymes, while it reduced these variables of lipogenic enzymes in rats. However, we found that lignan was ineffective in modulating the activity of enzymes involved in hepatic fatty acid oxidation and synthesis in mice and hamsters. In addition, lignan failed to affect the gene expression of these enzymes in mice. Significant alterations in these variables were noted on a few occasions, but the changes were much less than those observed in rats. Therefore, it is apparent that species dependence exists in the physiological activity of dietary lignan in affecting hepatic fatty acid oxidation and synthesis. Similar results were obtained even when the feeding period was extended to $30 \mathrm{~d}$ (M Kushiro, TIde, unpublished results).

The potential roles of SREBP-1c and PPAR $\alpha$ in mediating regulation of hepatic lipogenesis and fatty acid oxidation respectively in response to dietary, hormonal or other stimuli have been well documented not only in 
Table 5. Degradation of sesamin and episesamin (nmol/100 $\mu$ g protein) by liver microsomal enzyme preparation*

(Mean values and standard deviations)

\begin{tabular}{|c|c|c|c|c|c|c|}
\hline & \multicolumn{2}{|c|}{ Mouse } & \multicolumn{2}{|c|}{ Hamster } & \multicolumn{2}{|c|}{ Rat } \\
\hline & Mean & SD & Mean & SD & Mean & SD \\
\hline \multicolumn{7}{|c|}{ + NADPH† } \\
\hline \multicolumn{7}{|c|}{15 min incubation } \\
\hline Sesamin & $0.41^{a}$ & 0.30 & $1.40^{b}$ & 0.16 & $0.69^{a}$ & 0.14 \\
\hline Episesamin & $1 \cdot 39^{\mathrm{b}}$ & 0.27 & $0.57^{a}$ & 0.12 & $0.64^{a}$ & 0.26 \\
\hline Total & $1 \cdot 80^{\mathrm{ab}}$ & 0.56 & $1.97^{b}$ & 0.24 & $1.33^{a}$ & 0.35 \\
\hline \multicolumn{7}{|c|}{30 min incubation } \\
\hline Sesamin & $1 \cdot 33^{\mathrm{a}}$ & 0.27 & $2 \cdot 19^{b}$ & 0.20 & $1 \cdot 22^{\mathrm{a}}$ & 0.10 \\
\hline Episesamin & $2 \cdot 31^{b}$ & 0.21 & $1.06^{a}$ & 0.10 & $0.92^{a}$ & 0.16 \\
\hline Total & $3.63^{b}$ & 0.43 & $3 \cdot 25^{\mathrm{b}}$ & 0.24 & $2 \cdot 14^{\mathrm{a}}$ & 0.22 \\
\hline \multirow{2}{*}{\multicolumn{7}{|c|}{$\begin{array}{l}- \text { NADPH } \ddagger \\
30 \text { min incubation }\end{array}$}} \\
\hline & & & & & & \\
\hline Sesamin & 0.10 & & 0.12 & & 0.08 & \\
\hline Episesamin & 0.01 & & 0.19 & & 0.14 & \\
\hline Total & 0.11 & & 0.31 & & 0.22 & \\
\hline
\end{tabular}

${ }^{a, b}$ Mean values with unlike superscript letters were significantly different $(P<0.05)$

${ }^{*}$ For details of diets and procedures, see pp. 377-378.

†Five animals per group.

$\ddagger$ Two animals per group.

rats, but also in mice and hamsters (Schoonjans et al. 1996; Peters et al. 1997; Horton et al. 1998; Horton \& Shimomura, 1999; Shimomura et al. 1999; Field et al. 2001; Guo et al. 2001; Ide et al. 2001; Minnich et al. 2001). Our previous studies strongly indicated that sesame lignan affects hepatic fatty acid synthesis and oxidation in rats through the mechanisms dependent on SREBP-1 and PPAR $\alpha$ respectively (Ashakumary et al. 1999; Ide et al. 2001). Our cDNA probe and antibody used to measure hepatic SREBP-1 mRNA and protein levels in the previous study (Ide et al. 2001) could not discriminate SREBP-1a and -1c. It has been demonstrated that expression of SREBP-1c is greater than that of $-1 \mathrm{a}$ in animal tissues (Horton et al. 1998; Horton \& Shimomura, 1999; Shimomura et al. 1999; Field et al. 2001). Therefore, it is most likely that down-regulation of SREBP-1c rather than $-1 \mathrm{a}$ is primarily responsible for lignan-dependent decrease in lipogenic enzyme gene expression. It is possible that sensitivity in response to various stimuli of SREBP-1c and PPAR $\alpha$ signalling pathways is different among animal species, and hence can account for differing effects of dietary lignan on hepatic fatty acid metabolism among mice, hamsters and rats. However, comparative studies to examine the speciesdependent differences in the sensitivity of these signalling pathways is totally lacking. Detailed studies are required to test this possibility. Although two-way ANOVA on serum insulin levels of rats and mice failed to detect significant effects of lignan, animal species or lignan $\times$ animal species interaction, the values were considerably lower in rats fed a lignan-containing diet than in those fed a lignan-free diet. However, the values were comparable between mice fed a lignan-containing diet and a lignanfree diet. It has been demonstrated that insulin treatment increases SREBP-1c mRNA levels in 3T3-L1 adipocytes (Le Lay et al. 2002) and rat liver (Shimomura et al. 1999). Hence, it is possible that alterations in serum insulin concentration trigger a SREBP-1-dependent mechanism to decrease gene expression of hepatic lipogenic enzymes in rats fed lignan.

We found that tissue sesamin and episesamin concentrations in animals fed on the lignan preparation differed considerably among animal species. The observation strongly indicates that the differences among animal species in the amounts of lignan remaining in tissues, rather than the sensitivity of SREBP-1c and PPAR $\alpha$ signalling pathways, can account for the species dependence of the physiological activity of lignan in affecting hepatic fatty acid metabolism. In addition, the sesamin:episesamin ratios in the liver and serum were far from the value that would be expected from the ratio in dietary lignan (sesamin:episesamin ratio 1) in most cases and were dependent on the animal species.

Predominance of episesamin compared with sesamin in the serum and liver of rats was consistent with the report by Umeda-Sawada et al. (1999), and this may account for the difference in the physiological activity of sesamin and episesamin in affecting hepatic fatty acid oxidation in rats (Kushiro et al. 2002). The sums of the tissue concentrations of sesamin and episesamin in both the liver and serum were much less in mice and hamsters than in rats. Therefore, it is thought that tissue lignan levels were too low to affect hepatic fatty acid metabolism in mice and hamsters.

Species-dependent alterations in tissue lignan concentrations may indicate that differences exist in the rate of absorption or metabolism of sesamin and episesamin among animal species. We found in the present study that these lignans are degraded by liver microsomes. Inclusion of NADPH in the reaction mixture was found to be obligatory to detect significant degradation of lignans, indicating that cytochrome $\mathrm{P} 450$ is involved in the degradation of sesamin and episesamin by microsomes. Nakai et al. (2003) recently demonstrated that sesamin is metabolized by rat liver microsomes. They identified two 
metabolites in the reaction mixture. The methylenedioxyphenyl moiety in the structure of sesamin was converted into a dihydrophenyl (catechol) moiety. They were identified as (1R,2S,5R,6S)-6-(3,4-dihydroxyphenyl)-2-(3,4methylenedioxyphenyl)-3,7-dioxabicyclo(3,3,0)octane and (1R,2S,5R,6S)-2,6-bis(3,4-dihydroxyphenyl)-3,7-dioxabicy clo(3,3,0)octane. However, the metabolite(s) of episesamin remained to be identified. We showed in the present study that the rate and substrate specificity of the enzyme reaction were considerably different among animal species. The combined value of the sesamin and episesamin degradation rate was $26-41 \%$ lower in the rats than in the other animal species. Therefore, the differences in the microsomal enzyme activities may account for the speciesdependent differences in tissue lignan concentrations. However, the total lignan concentrations in the serum and liver were six to twenty-eight times greater in rats than in hamsters and mice. Thus, it is rather difficult to ascribe the species-dependent differences in tissue lignan concentration completely to the diversity of microsomal lignan-degrading activity among animal species. Insolubility of sesamin and episesamin made the kinetic analysis of the enzyme reaction difficult. It is possible that differences in the actual rate of lignan degradation by microsomes among animal species are larger than those estimated in the present study. Although our assay condition is still not sufficient to elucidate the kinetic properties of lignan degradation activity, the current analyses also indicated that considerable diversity exists in the specificity of the enzyme reaction toward sesamin and episesamin among animal species. However, the current observations regarding the differences in the substrate specificity of the enzyme reaction do not necessarily comply with the species-dependent alterations in tissue sesamin:episesamin values. Optimization of the enzyme assay is required to draw a definite conclusion. In addition, it is possible that there are differences in the rate of absorption of these lignan compounds among animal species, hence accounting for the different tissue lignan concentrations.

Hamsters most resemble human subjects with respect to lipoprotein profiles (Goulinet \& Chapman, 1993; Bravo et al. 1994), basal rate of cholesterol and bile acid synthesis (Dietschy et al. 1993), and various aspects of lipoprotein transport and metabolism (Dietschy et al. 1993), compared with rats and mice. Moreover, various dietary and pharmacological interventions cause changes in lipoprotein profiles and metabolism of hamsters in a direction and magnitude similar to that of human subjects (Dietschy et al. 1993; Horton et al. 1995; Dietschy, 1998). In the current study, dietary lignan profoundly affected hepatic fatty acid metabolism accompanying the changes in serum lipid profiles in rats, but not in hamsters. Therefore, it is possible that dietary lignan does not affect lipid metabolism in human subjects, as was observed in hamsters. However, Hirata et al. (1996) reported that lignan decreased serum cholesterol levels in human subjects. Our current observations strongly indicate that the diversity in lignan metabolism can account for the species dependence of the physiological activity of dietary lignan in affecting hepatic fatty acid metabolism and serum lipid levels. Therefore, human studies to examine lignan metabolism may help to estimate the efficacy of lignan as a supplement in the human diet.

In conclusion, dietary lignan (the preparation containing equivalent amounts of sesamin and episesamin) greatly increased the hepatic activity and mRNA levels of enzymes involved in fatty acid oxidation, while it strongly down-regulated the activities of enzymes involved in lipogenesis in rats. However, no such alterations were confirmed in mice and hamsters. The differences among these animal species in the amount of lignan remaining in tissues may account for the species dependence of the physiological activity of lignan in affecting hepatic fatty acid oxidation and synthesis.

\section{References}

Akimoto K, Kitagawa Y, Akamatsu T, Hirose N, Sugano M, Shimizu S \& Yamada H (1993) Protective effects of sesamin against liver damage caused by alcohol or carbon tetrachloride in rodents. Ann Nutr Metab 37, 218-224.

American Institute of Nutrition (1977) Reports of the American Institute of Nutrition Ad Hoc Committee on standards for nutritional studies. J Nutr 107, 1340-1348.

Ashakumary L, Rouyer I, Takahashi Y, Ide T, Fukuda N, Aoyama T, Hashimoto T, Mizugaki M \& Sugano M (1999) Sesamin, a sesame lignan, is a potent inducer of hepatic fatty acid oxydation in the rat. Metabolism 48, 1303-1313.

Bravo E, Cantafora A, Calcabrini A \& Ortu G (1994) Why prefer the Golden Syrian Hamster (Mesocricetus auratus) to the Wistar rat in experimental studies on plasma lipoprotein metabolism? Comp Biochem Physiol B 107, 347-355.

Chavali SR, Zhong WW, Utsunomiya T \& Forse RA (1997) Decreased production of interleukin-1- $\beta$, prostaglandin- $E_{2}$ and thromboxane- $\mathrm{B}_{2}$, and elevated levels of interleukin- 6 and -10 are associated with increased survival during endotoxic shock in mice consuming diets enriched with sesame seed oil supplemented with Quil-A saponin. Int Arch Allergy Immunol 114, 153-160.

Chiang JYL (1991) Reversed-phase high-performance liquid chromatography assay of cholesterol $7 \alpha$-hydroxylase. Methods Enzymol 206, 483-491.

Dietschy JM (1998) Dietary fatty acids and the regulation of plasma low density lipoprotein cholesterol concentrations. J Nutr 128, 2, 444S-448S.

Dietschy JM, Turley SD \& Spady DK (1993) Role of liver in the maintenance of cholesterol and low density lipoprotein homeostasis in different animal species, including humans. J Lipid Res 34, 1637-1659.

Field FJ, Born E, Murthy S \& Mathur SN (2001) Gene expression of sterol regulatory element-binding proteins in hamster small intestine. J Lipid Res 42, 1-8.

Folch J, Lees M \& Sloane Stanley GH (1957) A simple method for the isolation and purification of total lipides from animal tissues. J Biol Chem 226, 497-509.

Fukuda Y, Nagata M, Osawa T \& Namiki M (1986) Contribution of lignan analogues to antioxidative activity of refined unroasted sesame seed oil. J Am Oil Chem Soc 63, 1027-1031.

Goulinet S \& Chapman MJ (1993) Plasma lipoproteins in the golden Syrian hamster (Mesocricetus auratus): heterogeneity of apoB- and apoA-I-containing particles. J Lipid Res 34, 943-959.

Gu JY, Wakizono Y, Tsujita A, Lim BO, Nonaka M, Yamada K \& Sugano M (1995) Effects of sesamin and $\alpha$-tocopherol, individually or in combination, on the polyunsaturated fatty acid 
metabolism, chemical mediator production, and immunoglobulin levels in Sprague-Dawley rats. Biosci Biotech Biochem 59, $2198-2202$.

Gu JY, Wakizono Y, Dohi A, Nonaka M, Sugano M \& Yamada K (1998) Effect of dietary fats and sesamin on the lipid metabolism and immune function of Sprague-Dawley rats. Biosci Biotech Biochem 62, 1917-1924.

Guo Q, Wang P-R, Milot DP, Ippolito MC, Hernandez M, Burton CA, Wright SD \& Chao Y (2001) Regulation of lipid metabolism and gene expression by fenofibrate in hamsters. Biochim Biophys Acta 1533, 220-232.

Hirata F, Fujita K, Ishikura Y, Hosoda K, Ishikawa $\mathrm{T}$ \& Nakamura H (1996) Hypocholesterolemic effect of sesame lignan in humans. Atherosclerosis 122, 135-136.

Hirose N, Doi F, Ueki T, Akazawa K, Chijiiwa K, Sugano M, Akimoto K, Shimizu S \& Yamada H (1992) Suppressive effect of sesamin against 7,12-dimethylbenz[a]-anthracene induced rat mammary carcinogenesis. Anticancer Res 12, $1259-1265$.

Hirose N, Inoue T, Nishihara K, Sugano M, Akimoto K, Shimizu S \& Yamada H (1991) Inhibition of cholesterol absorption and synthesis in rats by sesamin. J Lipid Res 32, 629-638.

Horton JD, Bashmakov Y, Shimomura I \& Shimano H (1998) Regulation of sterol regulatory element binding proteins in livers of fasted and refed mice. Proc Natl Acad Sci USA 95, 5987-5992.

Horton JD, Cuthbert JA \& Spady DK (1995) Regulation of hepatic $7 \alpha$-hydroxylase expression and response to dietary cholesterol in the rat and hamster. $J$ Biol Chem 270, 5381-5387.

Horton JD \& Shimomura I (1999) Sterol regulatory element-binding protein: activators of cholesterol and fatty acid biosynthesis. Curr Opin Lipidol 10, 143-150.

Ide T, Ashakumary L, Takahashi Y, Kushiro M, Fukuda N \& Sugano M (2001) Sesamin, a sesame lignan, decreases fatty acid synthesis in rat liver accompanying the down-regulation of sterol regulatory element binding protein-1. Biochim Biophys Acta 1534, 1-13.

Inoue H, Noguchi T \& Tanaka T (1986) Complete amino acid sequence of rat L-type pyruvate kinase deduced from the cDNA sequences. Eur J Biochem 154, 465-469.

Kabir Y \& Ide T (1996) Activity of hepatic fatty acid oxidation enzymes in rats fed $\alpha$-linolenic acid. Biochim Biophys Acta 1304, 105-119.

Kushiro M, Masaoka T, Hageshita S, Takahashi Y, Ide T \& Sugano M (2002) Comparative effect of sesamin and episesamin on the activity and gene expression of enzymes in fatty acid oxidation and synthesis in rat liver. J Nutr Biochem 13, 289-295.

Le Lay S, Lefrere I, Trautwein C, Dugail I \& Krief S (2002) Insulin and sterol-regulatory element-binding protein-1c
(SREBP-1C) regulation of gene expression in 3T3-L1 adipocytes. J Biol Chem 277, 35625-35634.

McGarry JD \& Brown NF (1997) The mitochondrial carnitine palmitoyltransferase system. From concept to molecular analysis. Eur J Biochem 244, 1-14.

Mannaerts GP, Debeer LC, Thomass J \& De Scepper PJ (1979) Mitochondrial and peroxisomal fatty acid oxidation in liver homogenate and isolated hepatocytes for control and clofibrate-treated rats. J Biol Chem 254, 4585-4595.

Matsumura Y, Kita S, Tanida Y, Taguchi Y, Morimoto S, Akimoto K \& Tanaka T (1998) Antihypertensive effect of sesamin. III Protection against development and maintenance of hypertension in stroke-prone spontaneously hypertensive rats. Biol Pharm Bull 21, 469-473.

Minnich A, Tian N, Byan L \& Bilder G (2001) A potent PPAR $\alpha$ agonist stimulates mitochondrial fatty acid $\beta$-oxidation in liver and skeletal muscle. Am J Physiol Endocrinol Metab 280, E270-E279.

Nakai M, Harada M, Nakahara K, Akimoto K, Shibata H, Miki W \& Kiso Y (2003) Novel antioxidative metabolites in rat liver with ingested sesamin. J Agric Food Chem 51, 1666-16670.

Nonaka M, Yamashita K, Iizuka Y, Namiki M \& Sugano M (1997) Effects of dietary sesaminol and sesamin on eicosanoid production and immunoglobulin level in rats given ethanol. Biosci Biotech Biochem 61, 836-839.

Noguchi T, Iritani N \& Tanaka T (1992) Molecular mechanism of induction of key enzymes related to lipogenesis. Proc Soc Exp Biol Med 200, 206-209.

Ogawa T, Makino T, Hirose N \& Sugano M (1994) Lack of influence of low blood cholesterol levels on pancreatic carcinogenesis after initiation with $N$-nitrosobis(2-oxopropyl)amine in Syrian Golden hamsters. Carcinogenesis 15, 1663-1666.

Peters JM, Hennuyer N, Staels B, Fruchart JC, Fievet C, Gonzalez FJ \& Auwerx J (1997) Alterations in lipoprotein metabolism in peroxisome proliferator-activated receptor $\alpha$-deficient mice. $J$ Biol Chem 272, 27307-27312.

Schoonjans K, Staels B \& Auwerx J (1996) Role of the peroxisome proliferator-activated receptor in mediating the effects of fibrates and fatty acids on gene expression. J Lipid Res 37, 907-925.

Shimomura I, Bashmakov Y, Ikemoto S, Horton JD, Brown MS \& Goldstein JL (1999) Insulin selectively increases SREBP-1c mRNA in the livers of rats with streptozotocin-induced diabetes. Proc Natl Acad Sci USA 96, 13656-13661.

Umeda-Sawada R, Ogawa M \& Igarashi O (1999) The metabolism and distribution of sesame lignans (sesamin and episesamin) in rats. Lipids 34, 633-637.

Yamashita K, Kagaya M, Higuti N \& Kiso Y (2000) Sesamin and $\alpha$-tocopherol synergistically suppress lipid-peroxide in rats fed a high docosahexaenoic acid diet. Biofactors 11, 11-13. 